\title{
APPLICATIONS OF OLIVINE-ORTHOPYROXENE-SPINEL OXYGEN GEOBAROMETERS TO THE REDOX STATE OF THE UPPER MANTLE.
}

\author{
Chen, ${ }^{(1)}$ Y.D.; Pearson, ${ }^{(1)}$ N.J.; O'Reilly, ${ }^{(1)}$ S.Y. and Griffin, ${ }^{(2)}$ W.L. \\ (1) School of Earth Sciences, Macquarie University, Sydney, N.S.W., 2109, Australia. (2) Division of Exploration \\ Geosciences, CSIRO, North Ryde, N.S.W., 2113, Australia.
}

\section{INTRODUCTION}

Early oxygen-specific electrochemical measurements of the "intrinsic oxygen fugacity" (e.g., Arculus and Delano, 1981; Arculus et al., 1984) on mantle xenoliths indicated that the Crdiopside group xenoliths (Wilshire and Shervais, 1975) were characterized by oxygen fugacities close to the iron-wustite (IW) buffer, while Al-augite group xenoliths were found to be more oxidized, with oxygen fugacities between QFM and the nickel-nickel oxide (NNO) buffer. More recently, O'Neill and Wall (1987), Mattioli and Wood (1988), Nell and Wood (in Wood et al., 1990) and Ballhaus et al. (1990) have calibrated the reaction $2 \mathrm{Fe}_{3} \mathrm{O}_{4}$ (in spinel) $+6 \mathrm{FeSiO}_{3}$ (in orthopyroxene) $=6 \mathrm{Fe}_{2} \mathrm{SiO}_{4}$ (in olivine) $+\mathrm{O}_{2}$ to calculate $\mathrm{fO}_{2}$ from the mineral chemistry of xenoliths, and applied these calibrations to upper mantle xenolith suites from a number of localities around the world. The results indicate a relative uniformity of $\mathrm{fO}_{2}$ values from the upper mantle with most values lying between the QFM and MW buffers. In the present study, we have calculated oxygen fugacities of more mantle xenolith suites using several calibrations of the olivine-orthopyroxene-spinel oxygen geobarometer.

\section{DATA SOURCES AND XENOLITH SUITES}

The mineral analyses we used in the calculation of oxygen fugacities are from mantle xenoliths from eastern Australia, eastern China and southern Africa. The eastern Australia's xenoliths include those from western Victoria and from northeastern and southeastern Queensland and cover both the Cr-diopside suite and the Al-augite suite. Many of western Victorian xenoliths have been cryptically or modally metasomatised (containing amphibole \pm mica \pm apatite) (Griffin et al., 1984; O'Reilly and Griffin, 1988; Griffin et al., 1988; O'Reilly et al., unpublished data). Modally-metasomatised (amphibole-bearing) xenoliths are also present in Queensland xenolith suite (Ewart and Grenfell, 1985; Chen et al., unpublished data) but are much less common than in the western Victorian suite. Eastern China's mantle xenoliths included in this study are exclusively $\mathrm{Cr}$-diopside suite and these are from seventeen localities spread over a distance of $5000 \mathrm{~km}$ of eastern China. In addition to our unpublished data, mineral analyses are taken from the literature (Fan and Hooper, 1989; Song and Frey, 1989). ' wo of the lherzolites contain garnet in addition to spinel. Several lherzolite xenoliths from Nushan, Anhui province, contain minor amount of amphibole. African xenoliths are mostly from kimberlites in southern Africa. Also included are some amphibole and/or mica-bearing spinel lherzolite xenoliths from basalts of the Rift Valley of northern Tanzania (Dawson and Smith, 1988). The mineral analyses of the southern African xenoliths are mainly from an unpublished data base of the Anglo American Research Laboratories with those in Carswell et al. (1984) included. Xenolith types include garnet-spinel harzburgite, garnet-spinel lherzolite, spinel harzburgite, spinel lherzolite, amphibole-bearing spinel harzburgite and amphibolebearing spinel lherzolite. The xenolith localities can be grouped into (1) on-craton; (2) craton margin; and (3) off-craton settings.

\section{RESULTS AND DISCUSSIONS}

The ranges of calculated oxygen fugacities. Among the four calibrations of the oxygen barometer we used in our calculation (O'Neill and Wall, 1987; Mattioli and Wood, 1988; Nell and Wood, 1990; Ballhaus et al., 1990), the results calculated by using the latter two calibrations agree better than those calculated by others. The ranges of oxygen fugacities summarized here refer only to those calculated by Ballhaus et al.'s calibration. The xenoliths from western Victoria, Australia, range from about $3 \log$ units below to $0.5 \log$ units above the QFM buffer with most being within 2 log units of QFM. The xenoliths from Queensland, Australia, and from various localities of eastern China have oxygen fugacities in general 
comparable to those of the western Victoria xenoliths. Both the temperature and the calculated oxygen fugacities for xenoliths from Africa cover wider ranges than are seen in the basalt-borne xenoliths from China and Australia, but the majority of samples still have oxygen fugacities between the QFM and MW buffers. These observations are consistent with the previous conclusions (e.g., O'Neill and Wall, 1987) that the Cr-diopside suite xenoliths record oxygen fugacities more oxidized than predicted by intrinsic oxygen fugacity measurements (e.g., Arculus and Delano, 1981; Arculus et al., 1984).

Cr-diopside series versus Al-augite series The Al-augite xenoliths from western Victoria and Queensland have oxygen fugacity values falling within the range defined by the $\mathrm{Cr}$-diopside xenoliths. This observation confirms those of O'Neill and Wall (1987) and Wood and Virgo (1989), and is in contrast with the finding from intrinsic oxygen fugacity studies that the Alaugite suite xenoliths are distinctly more oxidized than the Cr-diopside suite xenoliths (e.g., Arculus et al., 1984).

Garnet-absent versus garnet-bearing xenoliths There is not a clear-cut distinction in terms of calculated oxygen fugacities between the the garnet-bearing and the garnet-absent xenoliths in the southern African xenolith suite, but the oxygen fugacities of garnet-bearing xenoliths are in general higher than those of most garnet-absent samples. The two garnet-bearing xenoliths from eastern China have oxygen fugacities falling within the range defined by other garnet-absent xenoliths. In addition, there is also no systematic difference in oxygen fugacities for southern African xenoliths from on-craton, craton-margin and off-craton localities.

Effect of mantle metasomatism Mattioli et al. (1989) and Ballhaus et al. (1990) found that modally-metasomatised upper mantle xenoliths record higher oxygen fugacity than those without obvious evidence of metasomatism. In the the western Victorian xenolith suite, there is no general distinction on the basis of calculated oxygen fugacities between hydrous and anhydrous xenoliths. It is known that the cryptic and modal metasomatism of xenoliths is accompanied by elevated ${ }^{87} \mathrm{Sr} /{ }^{86} \mathrm{Sr}$ and lowered $\varepsilon_{\mathrm{Nd}}$ (O'Reilly and Griffin, 1988; Griffin et al., 1988); a plot of the calculated oxygen fugacities versus ${ }^{87} \mathrm{Sr} /{ }^{86} \mathrm{Sr}$ and $\varepsilon_{\mathrm{Nd}}$ shows a rough trend of increasing ${ }^{87} \mathrm{Sr} /{ }^{6} \mathrm{Sr}$ and decreasing $\varepsilon_{\mathrm{Nd}}$ with decreasing oxygen fugacity. In addition, the overall western Victorian xenolith suite is highly reduced although heavily metasomatised. This suggests that this particular type of mantle metasomatism is coupled with reduced oxygen fugacity. The metasomatising fluids beneath western Victoria have been speculated to be derived from a subducting slab. If this is correct, then the relatively low $\mathrm{fO}_{2}$ fluid derived from the slab might have been buffered by graphitic sediments in the slab cover (Shaw and Flood, 1981).

Mica- ( \pm amphibole)-bearing xenoliths in the African suite have relatively high $\mathrm{fO}_{2}$. Many high-T sheared garnet peridotite xenoliths of southern Africa suite, although they contain no hydrous phases, have been shown to be extensively metasomatised by infiltrating melts resulting in the addition of large amounts of garnet and clinopyroxene, as well as $\mathrm{Zr}, \mathrm{Y}, \mathrm{Na}$ and $\mathrm{Ti}$ (Smith and Boyd, 1987; Griffin et al., 1989). Griffin et al (1989) have suggested that the metasomatising melt is asthenosphere-derived. The highest oxygen fugacities among the African xenoliths are seen in some high-T garnet peridotites. This suggests that, in the African xenolith suite, metasomatism is coupled with increasing oxygen fugacities.

A combination of our data from the western Victoria and the African xenolith suites as well as the observation made by previous workers (e.g., Mattioli et al., 1989; Ballhaus et al., 1990), it is suggested that there is no consistent worldwide relation between mantle metasomatism and the oxygen fugacity of mantle xenoliths; the direction of change of oxygen fugacity probably depends on the source of the metasomatising fluids.

\section{REFERENCES}

Arculus, R. J., and Delano, J. W. (1981) Intrinsic oxygen fugacity measurements: Techniques and results for spinels from upper mantle peridotite and megacryst assemblages. Geochimica et Cosmochimica Acta, 45, 899-913.

Arculus, R. J., Dawson, J. B., Mitchell, R. H., Gust, D. A., and Holmes, R. D. (1984) Oxidation states of the upper mantle recorded by megacryst ilmenites in kimberlites and type A and B spinel lherzolites. Contributions to Mineralogy and Petrology, 85, 85-94. 
Ballhaus, C., Berry, R. F., and Green, D. H. (1990) High pressure experimental calibration of the olivine-orthopyroxene-spinel oxygen barometer - implications for redox conditions in the upper mantle. Contributions to Mineralogy and Petrology, in press.

Carswell, D. A., Griffin, W. L., and Kresten, P. (1984) Peridotite nodules from Ngopetsoeu and Lipelaneng kimberlites, Lesotho: A crustal or mantle origin. In J. Kornprobst, Ed., Kimberlites II: the mantle and crust-mantle relationships, p.229-43, Elsevier, Amsterdam.

Dawson, J. B., and Smith, J. V. (1988) Metasomatised and veined upper-mantle xenoliths from Pello Hill, Tanzania: Evidence for anomalously-light mantle beneath the Tanzanian sector of the East African Rift Valley. Contributions to Mineralogy and Petrology, 100, $510-527$.

Ewart, A., and Grenfell, A. (1985) Cainozoic volcanic centers of southeastern Queensland with special reference to the Main Range, Bunya Mountains and the volcanic centers of the northern Brisbane coastal region. Paper of the Geology Department of Queensland University, 11, 1-57.

Fan, Q. C., and Hooper, P. R. (1989) The mineral chemistry of ultramafic xenoliths of eastern China: Implications for upper mantle composition and the paleogeotherm. Journal of Petrology, 30, 1117-1158.

Griffin, W. L., Wass, S. Y., and Hollis, J. D. (1984) Ultramafic xenoliths from Bullenmerri and Gnotuk Maars, Victoria, Australia: Petrology of a sub-continental crust-mantle transition. Journal of Petrology, 25, 53-87.

Griffin, W. L., O'Reilly, S. Y. and Stabel, A. (1988) Mantle metasomatism beneath western Victoria, Australia: II Isotopic geochemistry of $\mathrm{Cr}$-diopside lherzolites and $\mathrm{Al}$-augite pyroxenites. Geochimica et Cosmochimica Acta, 52, 449-459.

Griffin, W.L., Smith, D., Boyd, F.R., Cousens, D.R., Ryan, C.G., Sie, S.H., and Suter, G.F. (1989) Trace-element zoning in garnets from sheared mantle xenoliths. Geochimica et Cosmochimica Acta, 53, 561-567.

Mattioli, G. S., and Wood, B. J. (1988) Magnetite activities across the $\mathrm{MgAl}_{2} \mathrm{O}_{4}-\mathrm{Fe}_{3} \mathrm{O}_{4}$ spinel join, with application to thermobarometric estimates of upper mantle oxygen fugacity. Contributions to Mineralogy and Petrology, 98, 148-162.

Mattioli, G. M., Baker, M. B., Rutter, M.J., and Stolper, E. M. (1989) Upper mantle oxygen fugacity and its relationship to metasomatism. Journal of Geology, 97, 521-536.

O'Neill, H. St. C., and Wall, V. J. (1987) The olivine-orthopyroxene-spinel oxygen geobarometer, the nickel precipitation curve, and the oxygen fugacity of the Earth's upper mantle. Journal of Petrology, 28, 1169-1191.

O'Reilly, S.Y., and Griffin, W. L. (1988) Mantle metasomatism beneath western Victoria: I. Metasomatic processes in Cr-diopside lherzolite. Geochimica et Cosmochimica Acta, 52, 433-447.

Shaw, S. E., and Flood, R. H. (1981) The New England Batholith, eastern Australia: geochemical variation in time and space. Journal of Geophysical Research, 86, B11, $10530-10544$.

Smith, D., and Boyd, F. R. (1987) Compositional heterogeneities in a high-temperature lherzolite nodule and implications for mantle processes. In P. H. Nixon, Ed., Mantle xenoliths, p.551-561, Wiley, New York.

Song, Y., and Frey, F. A. (1989) Geochemistry of peridotite xenoliths in basalt from Hannuoba, eastern China: Implications for subcontinental mantle heterogeneity. Geochimica et Cosmochimica Acta, 53, 97-113.

Wilshire, H. G., and Shervais, J. W. (1975) Al-augite and Cr-diopside ultramafic xenoliths in basaltic rocks from Western United States. Physics and Chemistry of the Earth, 9, 257-272.

Wood, B. J., Bryndzia, L. T., and Johnson, K. E. (1990) Mantle oxidation state and its relationship to tectonic environment and fluid speciation. Science, 248, 337-345. 